\section{Beep-beep! Roadrunner breaks petaflop barrier}

The US military's Roadrunner supercomputer has become the first machine to calculate at more than a quadrillion $\left(10^{15}\right)$ operations per second, thereby crossing the petaflop barrier.

The record was technically set on 25 May, in IBM's laboratories in Poughkeepsie, New York, using the LINPACK standard benchmark for comparing supercomputer performance. In early June, however, it achieved petaflop performance on a real-life application of modelling the human cortex, says David Turek, vice-president for 'deep computing' at IBM.

It thus beats the record of IBM's Blue Gene/L machine, based at the Lawrence Livermore National Laboratory in California, which managed about 500 teraflops $\left(10^{12}\right)$.

Roadrunner was built to run calculations to ensure the safety of the US nuclear stockpile, and is due to be delivered next month to the Los Alamos National Laboratory in New Mexico for that purpose. In the meantime, it will also run other calculations, including plasma physics, molecular dynamics and climate change.

\section{Physicist's involvement in historical race row disputed}

A historical investigation has posthumously cleared Eligio Perucca, a physics professor at the Polytechnic University of Turin, of alleged anti-semitism towards Primo Levi.

Levi, an Italian chemist, writer and

Auschwitz survivor, described in his book The Periodic Table the difficulties he had faced in persuading several professors in Turin to take him on as a doctoral candidate in 1940, because of the race laws that the Fascist regime

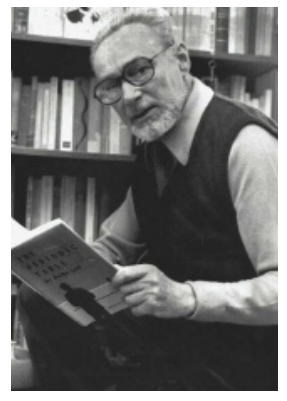

Primo Levi. imposed in Italy at that time. Perucca was later fingered as one of these professors in a Levi biography.

But Bart Kahr, a chemist at the University of Washington in Seattle, has looked into the claim and deduced that Perucca was not a fascist nor an anti-semite.

What's more, the investigation credits Perucca with a chemical discovery - of a certain type of optical activity, called optical rotary dispersion, of dyed chiral sodium chlorate crystals - in 1919 that was thought to have been discovered only in 1931.

\title{
Japanese lab installed on space station
}

Astronauts installed the main piece of Japan's laboratory module, Kibo, aboard the International Space Station last week.

At 11 metres long, Kibo, delivered by the space shuttle Discovery and opened by Japanese astronaut Akihiko Hoshide (pictured), is the largest pressurized research facility in space. Its final section, for work in unpressurized environments, is slated to be flown up next year. Astronauts also tested Kibo's robotic arm, which will be used to manipulate experiments on that final section when installed.

The station's malfunctioning toilet was also fixed during the trip.

\section{Panel urges further review of controversial NIH lab}

A blue-ribbon panel last week told the National Institutes of Health (NIH) that it needs to conduct more studies if it hopes to see high-risk biosafety research conducted at a lab under construction at Boston University Medical Center in Massachusetts.

The panel, chaired by molecular biologist Adel Mahmoud of Princeton University in New Jersey, said that the agency should conduct risk assessments for 12 dangerous pathogens, including comparing the risks of each being released at urban, suburban and rural sites.

Advisers to NIH director Elias Zerhouni, who received the report on 6 June, offered some sharp criticism of the \$198-million project, most of which is being paid for by the NIH. Community concerns about the risks of the facility have led to it being challenged in both the state and federal courts.

\section{Publications follow policy on stem-cell research}

Countries with less restrictive policies for deriving human embryonic stem cells produce a disproportionate share of the field's publications, according to a new study (A. Levine Cell Stem Cell 2, 521-524; 2008).

By this measure, the United States was the worst performer: although $36 \%$ of scientific publications on human embryonic stem cells in 2006 had a US-based corresponding author, that compared with $46 \%$ of a control set of biomedical publications and $47 \%$ of publications on RNA interference, a less controversial 'hot' technology.

The study's author, bioethicist Aaron Levine of the Georgia Institute of Technology in Atlanta, notes that governments in the top five overperforming countries
(Singapore, United Kingdom, Israel, China and Australia) support research and permit derivation of new cell lines. Besides the United States, other underperformers included Japan, France and Switzerland. Both France and Japan also have less than the expected share of publications on RNA interference, and Levine suggests that scientists in those countries are less inclined to pursue emerging technologies.

\section{Senate climate debate suffers death by hot air}

Democratic leaders in the US Senate walked away empty-handed last week after a highly anticipated debate over climate-change legislation disintegrated into partisan bickering and delaying tactics.

The bill, which would have required a two-thirds cut in greenhouse-gas emissions by 2050 , died on 6 June on a procedural vote. Not a single amendment was considered, and no substantive votes were cast.

Opponents said the legislation would further increase energy prices and push US jobs overseas. The lowlight came as Republicans invoked an obscure Senate rule to force staff to read the entire 492-page bill aloud over the course of some nine hours.

Few had expected the legislation to pass, but Democrats and environmentalists had hoped for a substantive debate that would lay the groundwork for next year.

\section{Corrections}

The News story 'No star left behind' (Nature 453,$437 ; 2008$ ) misstated the number of constellations constructed for an index in starmatching software. The number of constellations is 800 million not 800,000 .

In the News story 'Climate anomaly is an artefact' (Nature 453, 569; 2008) we incorrectly stated that David Thompson was at the State University of Colorado in Boulder. He is in fact at the Colorado State University in Fort Collins. 